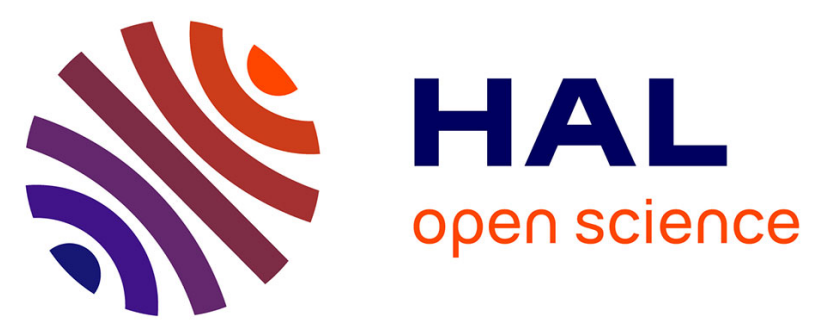

\title{
Tropospheric nitric acid columns from the IASI satellite instrument interpreted with a chemical transport model: Implications for parameterizations of nitric oxide production by lightning
}

\author{
Matthew Cooper, Randall V. Martin, Catherine Wespes, Pierre-François \\ Coheur, Cathy Clerbaux, Lee T. Murray
}

\section{To cite this version:}

Matthew Cooper, Randall V. Martin, Catherine Wespes, Pierre-François Coheur, Cathy Clerbaux, et al.. Tropospheric nitric acid columns from the IASI satellite instrument interpreted with a chemical transport model: Implications for parameterizations of nitric oxide production by lightning. Journal of Geophysical Research: Atmospheres, 2014, 119 (16), pp.10068-10079. 10.1002/2014JD021907 . hal-01056707

\section{HAL Id: hal-01056707 https://hal.science/hal-01056707}

Submitted on 31 Aug 2020

HAL is a multi-disciplinary open access archive for the deposit and dissemination of scientific research documents, whether they are published or not. The documents may come from teaching and research institutions in France or abroad, or from public or private research centers.
L'archive ouverte pluridisciplinaire HAL, est destinée au dépôt et à la diffusion de documents scientifiques de niveau recherche, publiés ou non, émanant des établissements d'enseignement et de recherche français ou étrangers, des laboratoires publics ou privés. 


\section{Journal of Geophysical Research: Atmospheres}

\section{RESEARCH ARTICLE \\ 10.1002/2014JD021907 \\ Key Points: \\ - Tropospheric $\mathrm{HNO}_{3}$ columns inferred from IASI using information from GEOS-Chem model \\ Tropospheric nitric acid columns from the IASI satellite instrument interpreted with a chemical transport model: Implications for parameterizations of nitric oxide production by lightning}

- GEOS-Chem underestimates tropospheric $\mathrm{HNO}_{3}$ in Southeast Asia

- Treatment of lightning $\mathrm{NO}_{x}$ is the most significant contributor to model bias

Correspondence to:

M. Cooper,

cooperm2@dal.ca

\section{Citation:}

Cooper, M., R. V. Martin, C. Wespes, P.-F. Coheur, C. Clerbaux, and L. T. Murray (2014), Tropospheric nitric acid columns from the IASI satellite instrument interpreted with a chemical transport model: Implications for parameterizations of nitric oxide production by lightning, J. Geophys. Res. Atmos., 119, 10,068-10,079, doi:10.1002/ 2014JD021907.

Received 14 APR 2014 Accepted 12 AUG 2014 Accepted article online 15 AUG 2014 Published online 27 AUG 2014

\author{
Matthew Cooper ${ }^{1}$, Randall V. Martin ${ }^{1,2}$, Catherine Wespes ${ }^{3}$, Pierre-Francois Coheur ${ }^{3}$, \\ Cathy Clerbaux ${ }^{3,4}$, and Lee T. Murray ${ }^{5}$
} Columbia University, New York, New York, USA
${ }^{1}$ Department of Physics and Atmospheric Science, Dalhousie University, Halifax, Nova Scotia, Canada, ${ }^{2}$ Harvard-Smithsonian Center for Astrophysics, Cambridge, Massachusetts, USA, ${ }^{3}$ Spectroscopie de l'Atmosphère, Chimie Quantique et Photophysique, Université Libre de Bruxelles, Brussels, Belgium, ${ }^{4}$ Sorbonne Universités, UPMC Univ. Paris 06; Université Versailles St-Quentin; CNRS/INSU, LATMOS-IPSL, Paris, France, ${ }^{5}$ NASA Goddard Institute for Space Studies and Lamont-Doherty Earth Observatory,

Abstract This paper interprets tropical tropospheric nitric acid columns from the Infrared Atmospheric Sounding Interferometer (IASI) satellite instrument with a global chemical transport model (GEOS-Chem). GEOS-Chem and IASI columns generally agree over the tropical ocean to within $10 \%$. However, the GEOS-Chem simulation underestimates IASI nitric acid over Southeast Asia by a factor of 2. The regional nitric acid bias is confirmed by comparing the GEOS-Chem simulation with additional satellite (High Resolution Dynamics Limb Sounder, Atmospheric Chemistry Experiment Fourier Transform Spectrometer) and aircraft (Pacific Exploratory Mission (PEM)-Tropics A and PEM-West B) observations of the middle and upper troposphere. This bias appears to be driven by the lightning $\mathrm{NO}_{x}$ parameterization, both in terms of the magnitude of the $\mathrm{NO}_{x}$ source and the ozone production efficiency of concentrated lightning $\mathrm{NO}_{x}$ plumes. We tested a subgrid lightning plume parameterization and found that an ozone production efficiency of $15 \mathrm{~mol} / \mathrm{mol}$ in lightning plumes over Southeast Asia in conjunction with an additional $0.5 \mathrm{Tg} \mathrm{N}$ would reduce the regional nitric acid bias from $92 \%$ to $6 \%$ without perturbing the rest of the tropics. Other sensitivity studies such as modified $\mathrm{NO}_{x}$ yield per flash, increased altitude of lightning $\mathrm{NO}_{x}$ emissions, decreased convective mass flux, or increased scavenging of nitric acid required unrealistic changes to reduce the bias.

\section{Introduction}

Nitrogen oxides $\left(\mathrm{NO}_{x} \equiv \mathrm{NO}+\mathrm{NO}_{2}\right)$ in the free troposphere largely control the production of ozone $\left(\mathrm{O}_{3}\right)$, an important greenhouse gas and atmospheric oxidant. The dominant sink for $\mathrm{NO}_{x}$ is oxidation to nitric acid $\left(\mathrm{HNO}_{3}\right) \cdot \mathrm{HNO}_{3}$ is one of the main forms of reactive nitrogen $\left(\mathrm{NO}_{y}\right)$ in the free troposphere, representing up to $50 \%$ of $\mathrm{NO}_{y}$ in the tropical upper troposphere [Kasibhatla et al., 1993; Folkins et al., 2006]. However, models generally have difficulty reproducing observed $\mathrm{NO}_{x} / \mathrm{HNO}_{3}$ ratios [Brunner et al., 2005; Singh et al., 2007]. Improved understanding of $\mathrm{HNO}_{3}$ production and loss mechanisms can help to better constrain $\mathrm{NO}_{x}$ emissions and in turn improve understanding of ozone production and its effect on climate.

Direct measurements of free tropospheric $\mathrm{HNO}_{3}$ are rare, particularly in the tropics. $\mathrm{HNO}_{3}$ measurements taken during aircraft campaigns offer high precision but have limited spatial and temporal coverage. Satellite instruments are capable of providing superior temporal and spatial sampling in the tropics. $\mathrm{HNO}_{3}$ concentrations have been retrieved from observations from several satellite instruments, including Limb Infrared Monitor of the Stratosphere [Gille et al., 1984], Michelson Interferometer for Passive Atmospheric Sounding [Tsidu et al., 2005], Microwave Limb Sounder (MLS) [Santee et al., 2004], Atmospheric Chemistry Experiment Fourier Transform Spectrometer (ACE-FTS) [Wolff et al., 2008], and High Resolution Dynamics Limb Sounder (HIRDLS) [Kinnison et al., 2008]. However, these instruments are primarily focused on high latitudes or stratospheric altitudes. In this study we use the Infrared Atmospheric Sounding Interferometer (IASI) instrument on the MetOp satellite platform. IASI is a high-resolution spectrometer that provides global observations of $\mathrm{HNO}_{3}$ column abundances with an unprecedented spatial and temporal resolution [Wespes et al., 2009]. 
Lightning $\mathrm{NO}_{x}$ has a large influence on tropospheric ozone and nitric acid, as lightning $\mathrm{NO}_{x}$ is emitted directly into the free troposphere where $\mathrm{NO}_{x}$ lifetimes are longer [Liu et al., 1987; Pickering et al., 1990; Sauvage et al., 2007]. Best estimates of the global lightning $\mathrm{NO}_{x}$ source range from 2 to $8 \mathrm{Tg} \mathrm{N} \mathrm{a}^{-1}$, but significant uncertainty remains in both the magnitude and vertical and horizontal distribution of the source [Martin et al., 2007; Schumann and Huntrieser, 2007]. A difficulty in modeling the effects of lightning $\mathrm{NO}_{x}$ is that lightning is a subgrid-scale process which must be parameterized in chemical transport models. Lightning parameterizations are most often based on meteorological properties and are sensitive to the convection scheme used in the model [Tost et al., 2007; Koshak et al., 2013]. Lightning $\mathrm{NO}_{x}$ production is often determined using a prescribed number of $\mathrm{NO}_{x}$ molecules produced per flash, but this value varies significantly between models [Schumann and Huntrieser, 2007]. $\mathrm{O}_{3}$ and $\mathrm{HNO}_{3}$ concentrations are sensitive to the vertical placement of lightning $\mathrm{NO}_{x}$ emissions [Labrador et al., 2005]. Uncertainty also arises when considering the dispersion rate of lightning $\mathrm{NO}_{x}$ plumes as rates of chemical reactions vary nonlinearly with respect to NO concentrations [Lin et al., 1988]. Since $\mathrm{HNO}_{3}$ is highly soluble and is quickly scavenged in convective updrafts, $\mathrm{HNO}_{3}$ concentrations are sensitive to convective mixing and wet deposition in models [Giorgi and Chameides, 1986; Mari et al., 2000; Staudt et al., 2003].

The following paper examines tropical tropospheric $\mathrm{HNO}_{3}$ columns retrieved from IASI satellite measurements. Section 2 describes data sources and other tools used in this work. Section 3 describes GEOS-Chem, a stateof-the-science global chemical transport model that is used here to interpret the IASI observations. Section 4 describes how GEOS-Chem is used to investigate the ability of IASI to provide information about $\mathrm{HNO}_{3}$ in the tropical troposphere. In the process of this evaluation, a bias in the GEOS-Chem $\mathrm{HNO}_{3}$ simulation over the tropical West Pacific and Indian Oceans is discovered. Section 5 discusses several possible methods for resolving the bias, including changes to wet deposition and lightning processes.

\section{Observational Data}

IASI was launched on the MetOp satellite in October 2006, into a polar Sun-synchronous orbit with an equator crossing time of 9:30 A.M. and P.M. [Clerbaux et al., 2009]. IASI is a nadir-viewing Fourier Transform Spectrometer measuring thermal infrared radiation between 645 and $2760 \mathrm{~cm}^{-1} . \mathrm{HNO}_{3}$ and $\mathrm{CO}$ profiles are retrieved with the Fast Operational/Optimal Retrievals on Layers for IASI processing chains set up by the Université libre de Bruxelles/Laboratoire Atmosphères, Milieux, Observations Spatiales (ULB/LATMOS) groups [Hurtmans et al., 2012]. The IASI $\mathrm{HNO}_{3}$ retrievals have $\sim 1$ degree of freedom of signal (DOFS) providing a total column for $\mathrm{HNO}_{3}$ offering no vertical information, except in the tropics where the DOFS reaches 1.5 [Wespes et al., 2009; Hurtmans et al., 2012]. IASI provides global coverage twice daily. Both day and night observations are used here. IASI scans across track either side of the nadir, with a total swath of around $2000 \mathrm{~km}$. Each field of view is composed of four circular pixels of $12 \mathrm{~km}$ diameter at nadir. IASI's vertical sensitivity to $\mathrm{HNO}_{3}$ is largest in the upper troposphere and lower stratosphere (approximately between 15 and $30 \mathrm{~km}$ ) with weak sensitivity near the surface. The lower tropospheric sensitivity is stronger in the tropics than in middle and polar latitudes because of higher surface temperatures [Clerbaux et al., 2009]. Evaluation of previous IASI $\mathrm{HNO}_{3}$ columns indicates average errors ranging from $12 \%$ at middle to high latitudes up to $32 \%$ near the equator [Wespes et al., 2009; Hurtmans et al., 2012]. The error is larger in the tropics due to stronger interferences with water vapor lines. Cloud information from the Eumetcast operational processing is used to reject observations with cloud coverage above $25 \%$. IASI CO has been demonstrated to be a performant product in terms of sensitivity (DOFS larger than 2 in the tropics) and retrieval errors (lower than 10\% in the tropics). Evaluation of IASI CO columns show discrepancies of about 7\% compared to other satellite instruments [George et al., 2009]. $\mathrm{HNO}_{3}$ and $\mathrm{CO}$ columns for the year 2008 are used in this study.

$\mathrm{HNO}_{3}$ observations from two other satellites, the High Resolution Dynamics Limb Sounder (HIRDLS) on the Aqua satellite and the Atmospheric Chemistry Experiment Fourier Transform Spectrometer (ACE-FTS), are used for vertical profile information. HIRDLS is a limb-scanning IR filter radiometer launched in 2004 on a near-polar Sun-synchronous orbit [Kinnison et al., 2008]. The vertical resolution in the tropical upper troposphere is approximately $1 \mathrm{~km}$. Individual profile precision in the retrieval is 10-15\%, but comparisons indicate a low bias of up to $30 \%$ relative to ACE-FTS and MLS satellite $\mathrm{HNO}_{3}$ observations [Kinnison et al., 2008]. Observations from 2005 to 2008 are used here. ACE-FTS is a solar occultation instrument measuring infrared radiation [Bernath et al., 2005]. Its orbit is optimized for high latitudes and thus provides infrequent observations in the tropics; however, complete coverage can be achieved if averaged over several years. Previous evaluation of 
ACE-FTS with aircraft measurements and the GEOS-Chem model indicates a positive bias in $\mathrm{HNO}_{3}$ of $15 \%$ in the tropical upper troposphere [Cooper et al., 2011]. Observations from 2004 to 2011 are used here.

We also use aircraft data from two of NASA's Pacific Exploratory Mission campaigns to evaluate the $\mathrm{HNO}_{3}$ simulation. The West Phase B (PEM-West B) consisted of 16 flights by the NASA DC-8 over the northwest Pacific Ocean in February-March 1994 [Hoell et al., 1997]. The Tropics Phase A (PEM-Tropics A) also used the DC-8 aircraft for 17 flights throughout the tropical Pacific between New Zealand and Hawaii from August to September 1996 [Hoell et al., 1999]. Individual $\mathrm{HNO}_{3}$ measurement accuracy is reported as 30-35\% [Hoell et al., 1999].

Ozonesonde measurements at Kuala Lumpur $\left(2.7^{\circ} \mathrm{N}, 101.7^{\circ} \mathrm{E}\right)$ are also used to evaluate the ozone simulation. These measurements are part of the Southern Hemisphere Additional Ozonesondes (SHADOZ) (http://croc.gsfc. nasa.gov/shadoz/) network, a group of 16 ozonesonde sites in the southern tropics [Thompson et al., 2003a, 2003b]. A total of 235 ozone profiles taken from the years 1998 to 2007 are used here.

\section{GEOS-Chem}

The GEOS-Chem global 3-D chemical transport model [Bey et al., 2001] version 9-01-03 (http://geos-chem.org) is used to interpret the IASI $\mathrm{HNO}_{3}$ observations. GEOS-Chem is driven by assimilated meteorological data provided by the Global Modeling and Assimilation Office (GMAO) at NASA Goddard Space Flight Center. GEOS-5 meteorological fields for the year 2008 degraded to a horizontal resolution of $4^{\circ} \times 5^{\circ}$ are used here. The GEOS-Chem simulation has 47 vertical levels, extending from the surface to $0.1 \mathrm{hPa}$ including approximately 35 levels in the troposphere. GEOS-5 employs the relaxed Arakawa-Schubert convective parameterization for shallow and deep moist convection [Moorthi and Suarez, 1992].

GEOS-Chem contains a detailed simulation of $\mathrm{HO}_{x}-\mathrm{NO}_{x}-\mathrm{VOC}-\mathrm{O}_{3}$-aerosol chemistry in the troposphere, including the most recent Jet Propulsion Laboratory/International Union of Pure and Applied Chemistry recommendations as implemented into GEOS-Chem by Mao et al. [2010]. The global lightning $\mathrm{NO}_{x}$ source of $6 \mathrm{Tg} \mathrm{N} \mathrm{a}^{-1}$ was constrained using satellite and ozonesonde observations [Martin et al., 2002, 2007] and is consistent with the $5.5 \pm 2.0 \mathrm{Tg} \mathrm{N} \mathrm{a}^{-1}$ used in current models [Stevenson et al., 2013] and more recent topdown estimates from satellite observations of $6.3 \pm 1.4 \mathrm{Tg} \mathrm{N} \mathrm{a}^{-1}$ [Miyazaki et al., 2014]. $\mathrm{NO}_{x}$ is distributed within simulated deep convection in a manner consistent with satellite climatologies of lightning flashes as described by Murray et al. [2012]. Lightning $\mathrm{NO}_{x}$ emissions are distributed relative to the cloud top height according to profiles based on aircraft observations and 3-D cloud-scale model simulations [Ott et al., 2010]. Anthropogenic $\mathrm{NO}_{x}$ and $\mathrm{CO}$ sources are from the Emission Database for Global Atmospheric Research inventory [Olivier, 2001] and overwritten by regional inventories in the northern midlatitudes. Biomass burning emissions of $\mathrm{NO}_{x}$ and $\mathrm{CO}$ are from the Global Fire Emissions Database v3 [van der Werf et al., 2010]. Biogenic $\mathrm{CO}$ emissions are from the Model of Gases and Aerosols from Nature (MEGAN) inventory of Guenther et al. [2012] as implemented by Barkley et al. [2011]. The mean tropical OH concentration is $1 \times 10^{6} \mathrm{molec} / \mathrm{cm}^{3}$. The stratospheric ozone simulation uses the Linoz algorithm of McLinden et al. [2000]. Monthly mean production rates and loss frequencies for other gases in the stratosphere are computed using archived data from the Global Modeling Initiative model [Murray et al., 2013]. The wet deposition scheme used in GEOS-Chem is described in Liu et al. [2001] with updates to subgrid scavenging by Wang et al. [2013]. $\mathrm{HNO}_{3}$ is highly soluble and is often completely scavenged within the convective updraft [Mari et al., 2000].

\section{Interpreting IASI Tropospheric $\mathrm{HNO}_{3}$ Columns and Results}

A major challenge in inferring tropospheric $\mathrm{HNO}_{3}$ columns from IASI observations is determining which portion of the column can be attributed to the troposphere. The coarse vertical sensitivity of IASI makes this difficult, as tropospheric $\mathrm{HNO}_{3}$ features are smoothed in the retrieval such that they overlap into the stratosphere and vice versa.

In the comparisons that follow, GEOS-Chem (GC) profiles are smoothed using the IASI averaging kernels to simulate IASI's coarse vertical resolution. A separate averaging kernel is used for each GC grid box. This is done using the method developed by Rodgers and Conner [2003]:

$$
\boldsymbol{x}_{\mathrm{GC}}^{\prime} \approx \boldsymbol{X}_{\boldsymbol{a}}+\boldsymbol{A}\left(\boldsymbol{x}_{\mathrm{GC}}-\boldsymbol{x}_{\boldsymbol{a}}\right)
$$

where $\boldsymbol{x}_{\mathrm{GC}}$ is the vertical $\mathrm{HNO}_{3}$ profile from GEOS-Chem, $\boldsymbol{x}_{\boldsymbol{a}}$ is the a priori profile used in the IASI retrievals, 

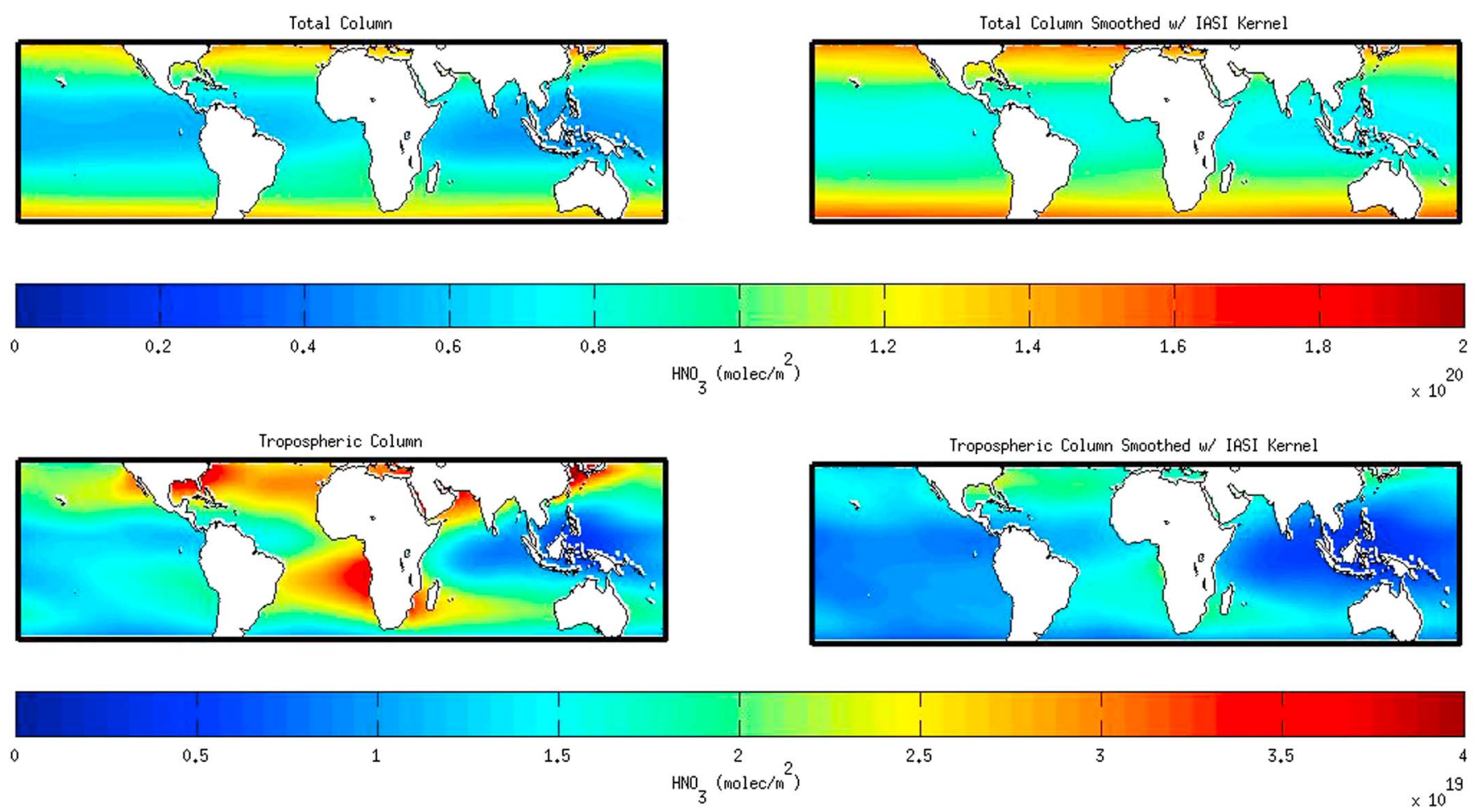

Figure 1. GEOS-Chem simulated $\mathrm{HNO}_{3}$ columns. Subplots contain the (top) total column and total column after smoothing with IASI averaging kernels and (bottom) tropospheric column and tropospheric column after smoothing with IASI averaging kernels.

$\boldsymbol{A}$ is the IASI averaging kernel matrix, and $\boldsymbol{x}_{\mathrm{GC}}{ }$ is the smoothed GEOS-Chem profile. The smoothed profile is then summed vertically to give a column value which can be compared to columns retrieved from IASI. A similar method of smoothing GEOS-Chem with remote sensing instrument averaging kernels to examine tropospheric ozone was used by Zhang et al. [2010].

For consistency with IASI, we first scaled the GEOS-Chem stratospheric $\mathrm{HNO}_{3}$ production and loss rates such that the smoothed total $\mathrm{HNO}_{3}$ column over the remote Pacific Ocean $\left(20^{\circ} \mathrm{S}-20^{\circ} \mathrm{N}, 140^{\circ}-180^{\circ} \mathrm{W}\right)$ matches the IASI column. Over the remote tropical Pacific Ocean, tropospheric $\mathrm{HNO}_{3}$ concentrations are a small fraction (10\%) of the total column abundance, and thus, the column can be treated as primarily stratospheric. Zonal symmetry in stratospheric $\mathrm{HNO}_{3}$ concentrations then allows this scaling to be applied throughout the tropics. This results in a $25 \%$ average reduction in smoothed total simulated $\mathrm{HNO}_{3}$ columns across the tropics.

We use GEOS-Chem to aid the separation of the stratospheric and tropospheric columns. Stratospheric columns in GEOS-Chem are calculated by setting the simulated tropospheric concentrations to zero before smoothing the simulated profiles with the IASI averaging kernels:

$$
\boldsymbol{x}_{\mathrm{GC} \_ \text {strat }}^{\prime} \approx \boldsymbol{x}_{\boldsymbol{a}}+\boldsymbol{A}\left(\boldsymbol{x}_{\mathrm{GC}(\text { troposphere }=0)}-\mathbf{x}_{\boldsymbol{a}}\right)
$$

The tropospheric columns are then calculated by subtracting the smoothed GEOS-Chem stratospheric columns from both the smoothed model total columns and the IASI total columns $\left(\Omega_{\mathrm{IASI}}\right)$ :

$$
\begin{aligned}
& \text { Smoothed GC Trospospheric Column }=\sum_{z=0}^{\infty} \boldsymbol{x}_{\mathrm{GC}}^{\prime}-\sum_{z=0}^{\infty} \boldsymbol{x}_{\mathrm{GC} \_ \text {strat }}^{\prime} \\
& \text { IASI Trospospheric Column }=\Omega_{\text {IASI }}-\sum_{z=0}^{\infty} \boldsymbol{x}_{\mathrm{GC} \_ \text {strat }}^{\prime}
\end{aligned}
$$

where $z$ is the altitude. Potential errors in the GEOS-Chem tropospheric column over the remote tropical Pacific may contribute to offset in the IASI tropospheric columns, but that offset would cancel in the difference (IASI minus GEOS-Chem) on which we focus below. 

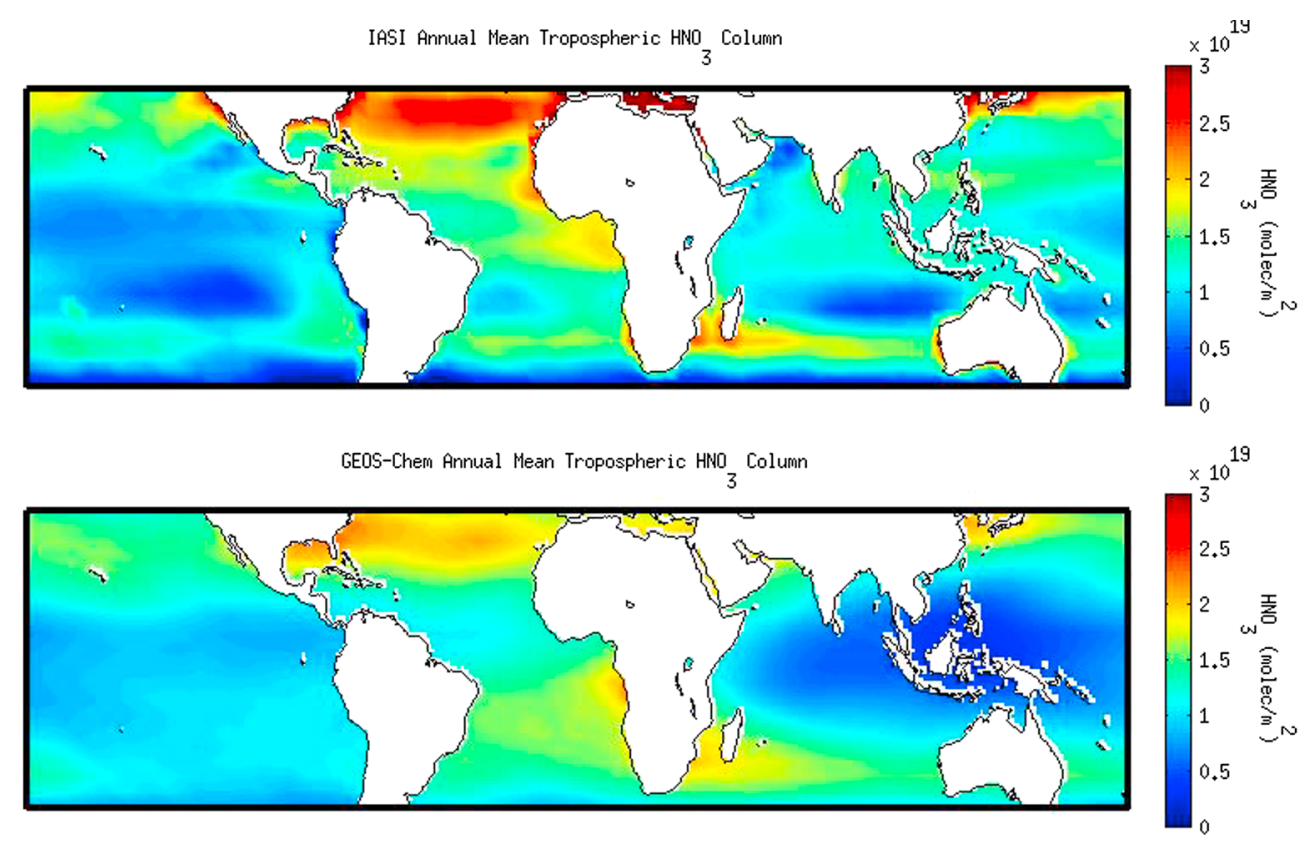

IASI - GEOS-Chem Percent Difference

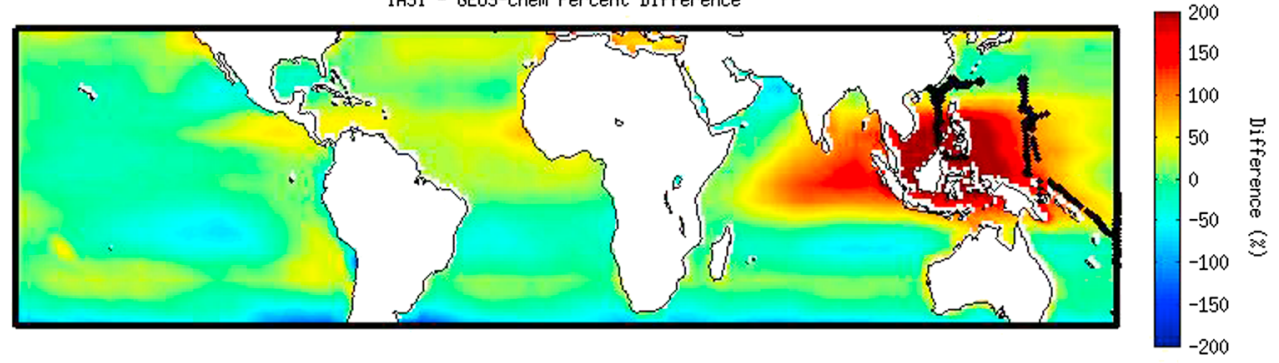

Figure 2. Annual mean tropospheric $\mathrm{HNO}_{3}$ columns for 2008 from (top) IASI and (middle) GEOS-Chem. (bottom) The difference between IASI and GEOS-Chem. The location of PEMWest-B and PEM-Tropics A flight paths used here are shown in black in Figure 2 (bottom).

Figure 1 shows the effect of smoothing GEOS-Chem with the IASI averaging kernel. As IASI is most sensitive to the stratosphere and has coarse vertical resolution, the smoothing enhances the stratospheric component relative to the tropospheric component, leading to an apparent average reduction in the tropospheric column of $37 \%$. This value is independent of the scaling of the stratosphere and describes a source of uncertainty in the IASI tropospheric columns due to the instrument's vertical sensitivity. Figure 1 (bottom) shows that the broad spatial patterns are retained in the smoothed tropospheric columns.

Figure 2 shows annual mean tropospheric $\mathrm{HNO}_{3}$ columns from IASI and GEOS-Chem. Emissivity features over deserts cause overestimations in the IASI columns [Wespes et al., 2009], and while this problem is largely confined to desert regions, we have ignored all observations over land as a precaution. GEOS-Chem is generally consistent with IASI over the tropics with a mean difference of $15 \%$ and a similar spatial distribution. Low concentrations over the Pacific Ocean and elevated concentrations over the tropical Atlantic are visible in both IASI and GEOS-Chem. However, IASI columns are up to twice as high as those in the simulation over the Indian Ocean and West Pacific Ocean regions (defined by $60^{\circ}-160^{\circ} \mathrm{E}, 15^{\circ} \mathrm{S}-15^{\circ} \mathrm{N}$, here referred to as Southeast Asia), and the Atlantic/Pacific contrast is stronger in the simulation. This bias exists throughout the year. As measurement errors in the IASI retrievals are not higher in this region than elsewhere in the tropics [Hurtmans et al., 2012], the simulation is the likely source of the bias.

Figure 3 provides further evidence of a model bias through comparisons with additional satellite data. Figure 3 (column 1) shows the relative deviation from the tropical mean tropospheric $\mathrm{HNO}_{3}$ columns near the equator $\left(10^{\circ} \mathrm{S}-10^{\circ} \mathrm{N}\right.$ ) as a function of longitude for IASI and GEOS-Chem. Figure 3 (column 2) shows 


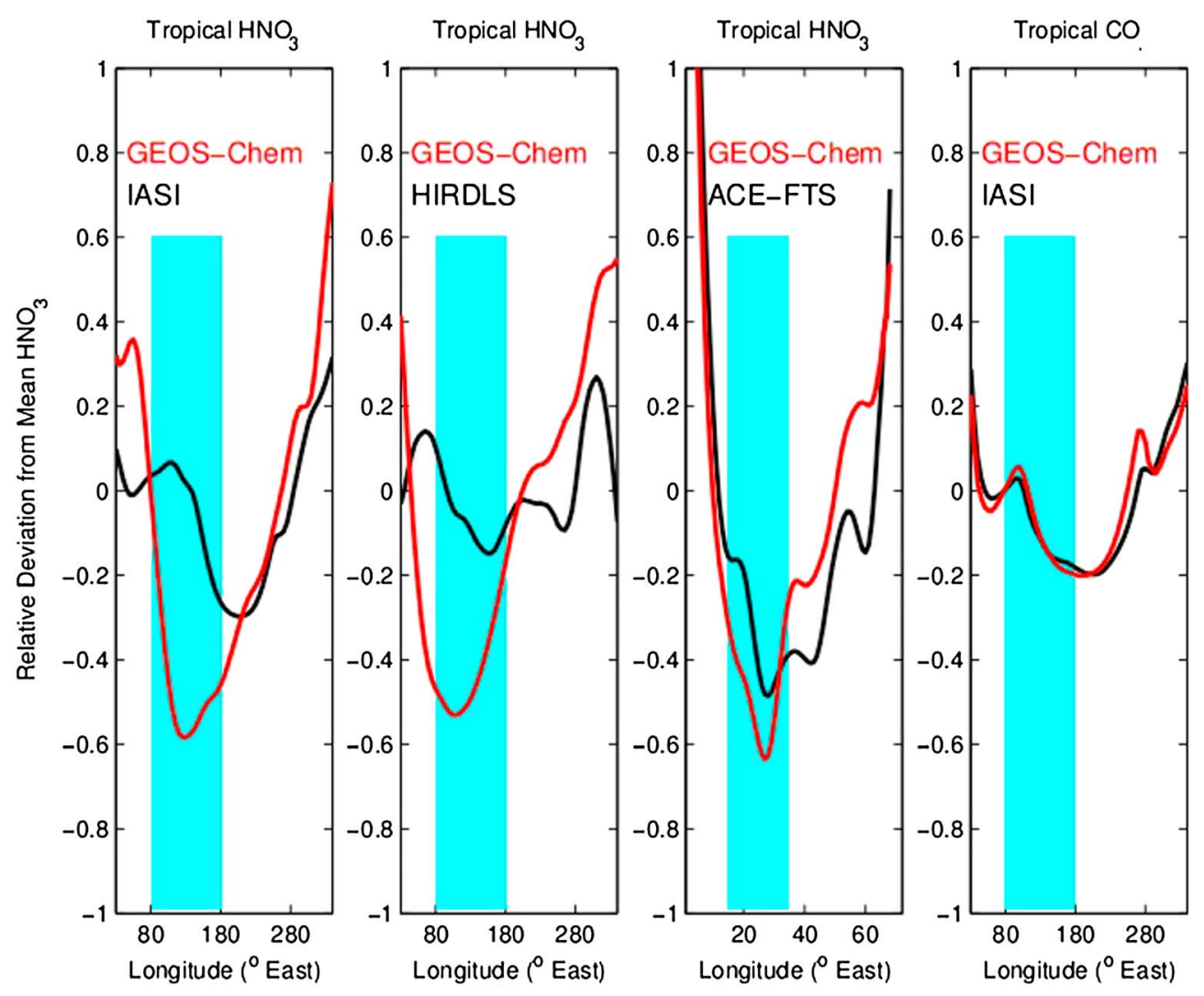

Figure 3. Relative deviation from tropical mean $\mathrm{HNO}_{3}$ over $10^{\circ} \mathrm{S}-10^{\circ} \mathrm{N}$. From left to right, (column 1) GEOS-Chem and IASI $\mathrm{HNO}_{3}$ tropospheric columns, (column 2) GEOS-Chem and HIRDLS HNO 3 mixing ratios at $163 \mathrm{hPa}$, (column 3) GEOS-Chem and ACE-FTS $\mathrm{HNO}_{3}$ mixing ratios at $245 \mathrm{hPa}$, and (column 4) GEOS-Chem and IASI CO total columns. Figure 3 (columns 1-3) shows an underestimation in GEOS-Chem $\mathrm{HNO}_{3}$ over Southeast Asia (shaded region spanning longitudes $80^{\circ}-180^{\circ}$ ). Figure 3 (column 4) shows no bias over Southeast Asia.

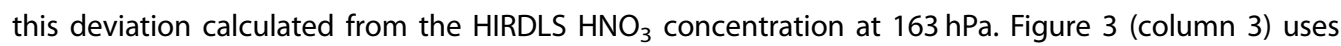
ACE-FTS $\mathrm{HNO}_{3}$ concentrations near $245 \mathrm{hPa}$. GEOS-Chem is sampled the location and day of observations for each instrument. Since IASI gives column values and ACE-FTS and HIRDLS provide upper tropospheric concentrations, all three plots are normalized by their tropical mean values to facilitate comparisons, as well as to reduce the effect of instrument biases. All three plots show the familiar wave-one pattern of elevated concentrations over the tropical Atlantic (longitude range $0^{\circ}-20^{\circ}$ and $310^{\circ}-360^{\circ}$ ). IASI shows a small local maximum over the Southeast Asia region (longitudes $60^{\circ}-160^{\circ} \mathrm{E}$ ) that is more pronounced than that seen in the plots for ACE-FTS or HIRDLS. Differences between instruments likely reflect different vertical layers of observation (column versus upper troposphere) and sampling differences in this cloudy region. However, all three plots also show that GEOS-Chem underestimates $\mathrm{HNO}_{3}$ Over this region. The ACE-FTS plot is consistent with previous evaluations of GEOS-Chem by Cooper et al. [2011], which showed that GEOS-Chem underestimates $\mathrm{NO}_{y}$ concentrations relative to $\mathrm{MOZAIC}$ and $\mathrm{HNO}_{3}$ relative to ACE-FTS in the region.

Figure 4 shows vertical $\mathrm{HNO}_{3}$ profiles from measurements made in the Southeast Asia region only during the PEM-West B and PEM-Tropics A aircraft campaigns and from GEOS-Chem. The simulation is run using GMAO MERRA reanalysis meteorological fields for the campaign years (1994 for PEM-West B and 1996 for PEM-Tropics A) and is sampled along the aircraft flight path at the same location, altitude, and time of the observations. The simulation is consistently lower than the aircraft measurements by a factor of 2-3 throughout the middle and upper troposphere. This supports the bias in the simulation, as this is a consistent feature over a large vertical and horizontal range observed independently by satellite and aircraft measurements. 


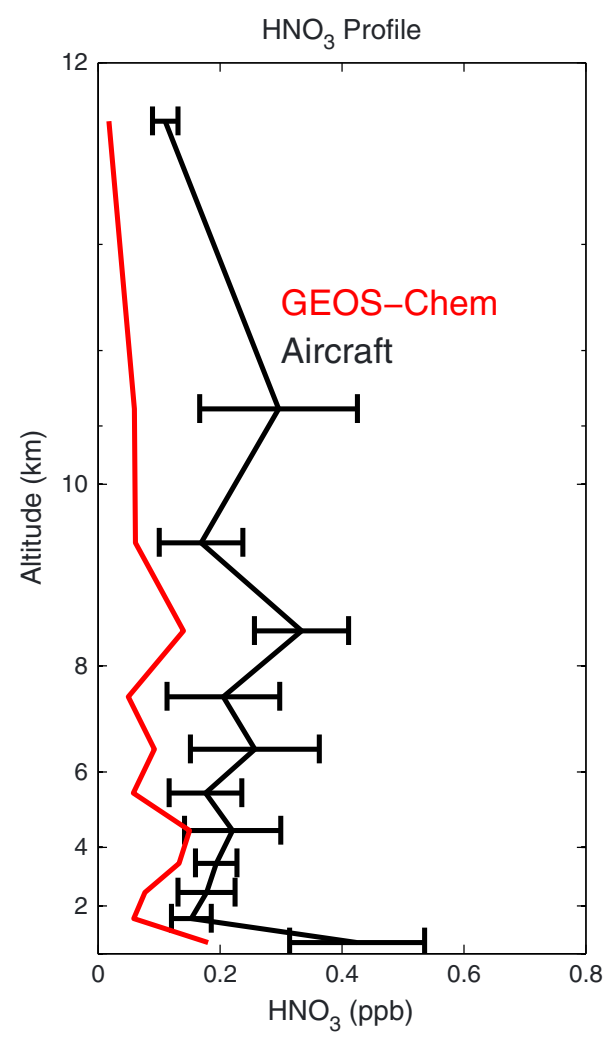

Figure 4. Average $\mathrm{HNO}_{3}$ profiles from aircraft campaigns (PEM-West B and PEM-Tropics A) and from GEOS-Chem sampled along the flight paths. Error bars indicate 1 standard error from the mean.

\section{Understanding the GEOS-Chem Bias \\ In the following sections we examine the most likely sources of the model underestimate in Southeast Asia: transport errors, the lightning $\mathrm{NO}_{x}$ source and its subsequent chemical processes, and overly vigorous wet deposition.}

\subsection{Mixing Processes}

$\mathrm{CO}$ measurements are useful in model evaluation as combustion $\mathrm{NO}_{x}$ sources are collocated with $\mathrm{CO}$ emissions, and the lifetime of $\mathrm{CO}$ is sufficiently long to evaluate transport [Jaeglé et al., 1998]. Figure 3 (column 4) shows the relative deviation from the tropical mean $\mathrm{CO}$ total columns for GEOS-Chem and IASI. The deviation from the mean in the GEOS-Chem simulation agrees well with IASI throughout the tropics, including the Southeast Asia region where the bias in $\mathrm{HNO}_{3}$ exists. The absence of errors in $\mathrm{CO}$ indicates that transport from combustion sources is an unlikely contributor to the $\mathrm{HNO}_{3}$ bias. We next turn to lightning $\mathrm{NO}_{x}$ as a potential contributor to the $\mathrm{HNO}_{3}$ bias that is independent of $\mathrm{CO}$.

\subsection{Lightning $\mathrm{NO}_{x}$ Yield per Flash}

We first examine the magnitude of the lightning $\mathrm{NO}_{x}$ source over Southeast Asia. In the year 2008 the standard GEOS-Chem simulation has a lightning $\mathrm{NO}_{x}$ source of $6.2 \mathrm{Tg} \mathrm{N} \mathrm{a}^{-1}$. Figure 5 shows the effect of adding additional lightning $\mathrm{NO}_{x}$ to the free troposphere. A factor of 3.5 increase in lightning $\mathrm{NO}_{x}$ yield/flash over Southeast Asia yields a $2.4 \mathrm{Tg} \mathrm{N} \mathrm{a}^{-1}$ increase in the total global annual mean lightning $\mathrm{NO}_{x}$ source to $8.6 \mathrm{Tg} \mathrm{N} \mathrm{a}^{-1}$. The GEOSChem $\mathrm{HNO}_{3}$ column bias versus IASI over the Indian Ocean and Indonesia is reduced from $92 \%$ to $7 \%$. Agreement is also improved over the West Pacific. Figure 6 evaluates the implications for the $\mathrm{O}_{3}$ simulation at Kuala Lumpur. The additional $\mathrm{NO}_{x}$ leads to increased ozone production which causes errors of $25 \%$ in the simulated ozone fields. This indicates that a simple increase in the lightning $\mathrm{NO}_{x}$ source is not the ideal solution to the simulated column $\mathrm{HNO}_{3}$ underestimate.

\subsection{Vertical Distribution of Lightning $\mathrm{NO}_{x}$}

The effects of lightning $\mathrm{NO}_{x}$ on tropospheric chemistry depend on its vertical distribution, as $\mathrm{NO}_{x}$ lifetimes and ozone production efficiencies generally increase with altitude [Labrador et al., 2005]. The profiles developed by Ott et al. [2010] used to distribute lightning $\mathrm{NO}_{x}$ emissions vertically are based on information from midlatitude and subtropical storms and might not be representative of tropical storms. We performed sensitivity studies by increasing the median injection height of tropical lightning NO emissions from 8.7 to $12.6 \mathrm{~km}$. We find that raising the $\mathrm{NO}$ injection height increases the $\mathrm{HNO}_{3}$ tropospheric column abundances throughout the tropics by as much as $25 \%$ but has little effect in the regions where lightning NO is emitted as shown in Figure $5 \mathrm{c}$. $\mathrm{NO}_{x}$ emitted at higher altitude has a longer lifetime and can be transported horizontally to form $\mathrm{HNO}_{3}$ away from the source region. This $\mathrm{HNO}_{3}$ also has a longer lifetime at these altitudes leading to the increased column abundances throughout the tropics. However, near the region of emission the increase in $\mathrm{HNO}_{3}$ produced at higher altitudes is largely balanced by decreases at lower altitudes and does not significantly change the column abundance. Thus, adjustments to the $\mathrm{NO}_{x}$ injection height do not improve the simulation bias in Southeast Asia. The resulting change in ozone concentrations throughout the tropics is generally less than a few parts per billion as shown in Figure 6. 
(a) IASI - GEOS-Chem Standard

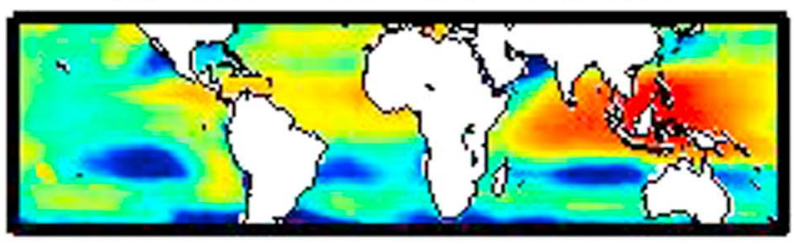

(b) IASI - GEOS-Chem w/3.5x SEAsia Flash Yield

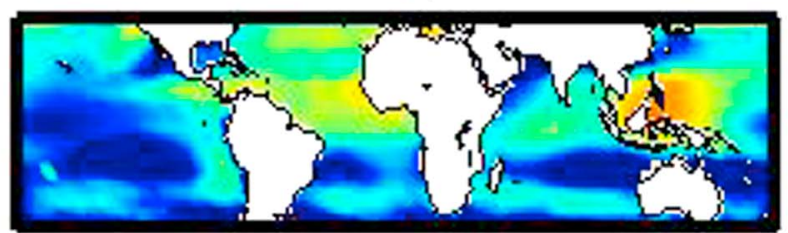

(c) IASI - GEOS-Chem w/ Increased NO In,jection Height

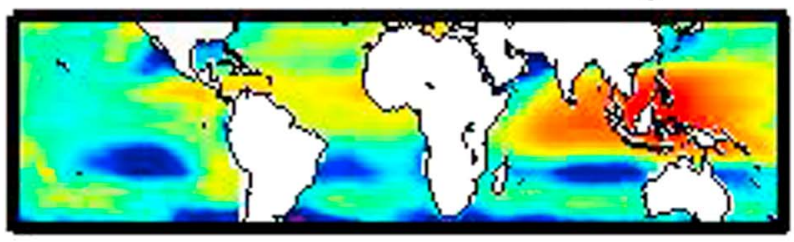

(d) IASI - GEOS-Chem w/ GTg N Added Globally

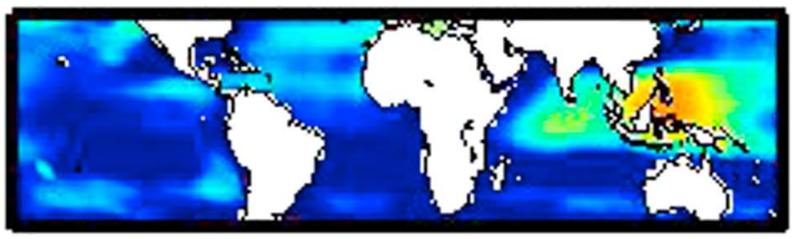

(e) IASI - GEOS-Chem w/ 0.5Tg N Added in SE Asia added

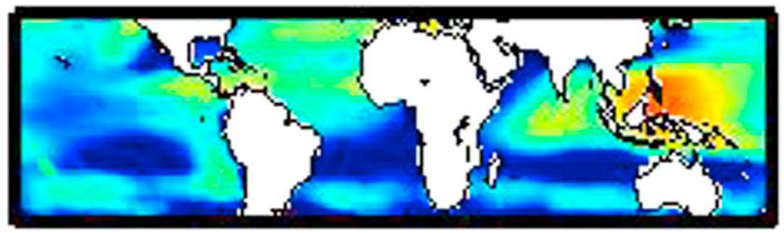

(f) IASI - GEOS-Chem w/ 75\% Convective Mass Flux
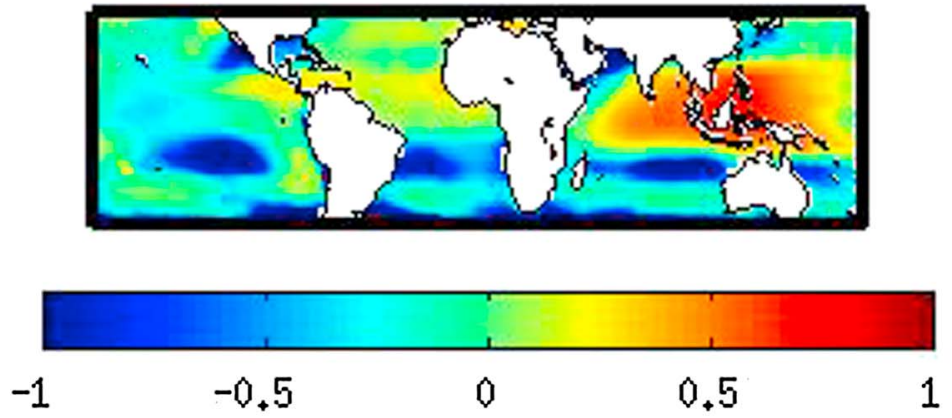

Fractional Difference

Figure 5. Fractional difference in annual mean tropospheric $\mathrm{HNO}_{3}$ columns between IASI and the following GEOS-Chem simulations: (a) standard simulation, (b) with flash yield increased by factor of 3.5 (c) with median NO injection height increased from 8.7 to $12.6 \mathrm{~km}$, (d) with $6 \mathrm{Tg}$ additional $\mathrm{HNO}_{3}$ globally, (e) with $0.5 \mathrm{Tg}$ additional $\mathrm{HNO}_{3}$ over Southeast Asia only, and (f) with convective mass fluxes reduced by $25 \%$. 


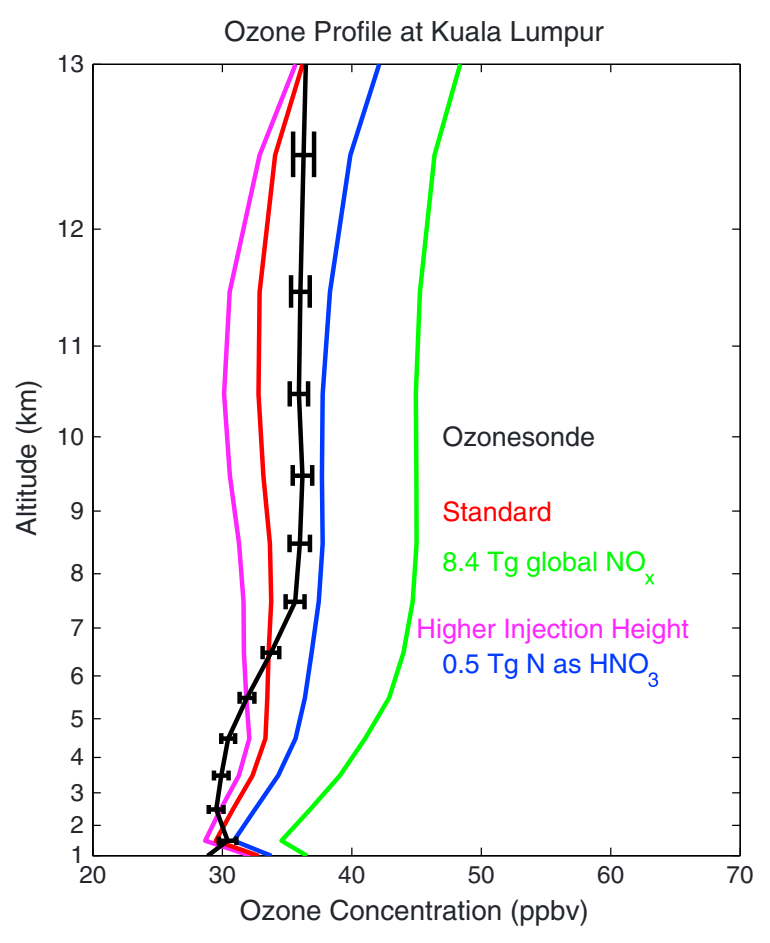

Figure 6. Annual mean ozone profile at Kuala Lumpur $\left(2.7^{\circ} \mathrm{N}, 101.7^{\circ} \mathrm{E}\right)$. Profiles from a standard GEOS-Chem simulation (red), a simulation with $0.5 \mathrm{Tg} \mathrm{HNO}_{3}$ added in Southeast Asia (blue), a simulation with the lightning NO source increased to $8.4 \mathrm{Tg}$ (green), a simulation with lightning NO injection height raised to $12.6 \mathrm{~km}$ (pink), and an annual mean profile from ozonesondes (black) are shown. Error bars represent the standard error in the ozonesonde measurements.

\subsection{Subgrid Plume Parameterization}

The method by which lightning $\mathrm{NO}_{x}$ is emitted in the simulation may contribute to the simulation bias. Lightning $\mathrm{NO}_{x}$ emitted into the GEOS-Chem grid boxes produce dilute NO plumes with typical concentrations less than 1 ppbv. Aircraft observations found that lightning can create highly concentrated NO plumes inside cumulonimbus clouds, with concentrations generally between 1 and 7 ppbv and occasionally rising as high as 25 ppbv [Huntrieser et al., 2002, 2009; Ott et al., 2010]. These concentrated plumes can have spatial scales as small as $300 \mathrm{~m}$ [Huntrieser et al., 2002], which are not resolved in global models with typical scales of $50-500 \mathrm{~km}$.

Ozone production from lightning $\mathrm{NO}_{x}$ is highly nonlinear with respect to $\mathrm{NO}_{x}$ concentration [Lin et al., 1988]. As a result, the dilute $\mathrm{NO}_{x}$ plumes created in GEOS-Chem overestimate the ozone production efficiency (OPE), or the number of ozone molecules produced per $\mathrm{NO}_{x}$ molecule consumed. This means that $\mathrm{O}_{3}$ is produced too efficiently and $\mathrm{HNO}_{3}$ is produced too inefficiently. Similar issues have been noted in the representation of plumes from power plants [Sillman et al., 1990], aircraft [Meijer et al., 1997], and ships [Vinken et al., 2011]. Changes

to the lightning $\mathrm{NO}_{x}$ parameterization which account for this nonlinearity may reduce the simulated $\mathrm{HNO}_{3}$ bias over Southeast Asia.

We explored this process by modifying the GEOS-Chem lightning simulation to account for the nonlinear chemistry that occurs in the early concentrated stage of a lightning $\mathrm{NO}_{x}$ plume before it dilutes to grid box scale. This is done by allowing some of the lightning $\mathrm{NO}$ to rapidly convert to $\mathrm{HNO}_{3}$ after a typical amount of ozone production. The ratio of $\mathrm{O}_{3}$ to $\mathrm{HNO}_{3}$ produced is treated as a constant OPE of 15 moles of $\mathrm{O}_{3}$ per mole of $\mathrm{HNO}_{3}$. This value was estimated by forcing $\mathrm{NO}_{x}$ concentrations in a GEOS-Chem grid box over Indonesia to 5 ppbv (near the middle of the measured 1-7 ppbv range for lightning plumes), calculating the instantaneous OPE and finding an average of 15 moles $\mathrm{O}_{3} /$ mole NO. This value is similar to those found by modeling studies for urban pollution (5-20 mol $/ \mathrm{mol}$ ) [Kleinman et al., 2002] and for aircraft $\mathrm{NO}_{x}$ emissions (10-28 mol $\left./ \mathrm{mol}\right)$ [Gilmore et al., 2013].

Figure $5 \mathrm{~d}$ shows the change in $\mathrm{HNO}_{3}$ from adding globally $6 \mathrm{Tg} \mathrm{N} \mathrm{yr}^{-1}$ with an OPE of $15 \mathrm{~mol} / \mathrm{mol}$. The lightning $\mathrm{NO}$ source was held fixed at $6 \mathrm{Tg} \mathrm{N} \mathrm{a}^{-1}$, while the amount of extra $\mathrm{N}$ (emitted as $\mathrm{HNO}_{3}$ ) and $\mathrm{O}_{3}$ was allowed to vary given uncertainty in plume dilution rates. The bias over Southeast Asia is reduced from $92 \%$ to $9 \%$ but at the expense of increasing the bias throughout the rest of the tropics to $-46 \%$.

It is possible that lightning plumes over Southeast Asia have different behavior than elsewhere as lightning $\mathrm{NO}_{x}$ yields are known to vary by region [Schumann and Huntrieser, 2007]. With this in mind, 0.5 $\mathrm{Tg} \mathrm{N}$ is added with an OPE of $15 \mathrm{~mol} / \mathrm{mol}$ over Southeast Asia only in Figure $5 \mathrm{e}$. The bias over Southeast Asia is reduced to $6 \%$ without negatively affecting the rest of the tropics. Figure 6 evaluates how the additional $\mathrm{O}_{3}(30 \mathrm{Tg})$ from this parameterization affects the $\mathrm{O}_{3}$ simulation. Free tropospheric ozone concentrations in Southeast Asia increased by up to 7 ppbv (up to a $17 \%$ increase) with small increases elsewhere. Ozone in the middle troposphere remains within $25 \%$ of ozonesondes at Kuala Lumpur. The processes affecting lightning $\mathrm{NO}_{x}$ over Southeast Asia differently than the rest of the globe is not fully 
understood at this time. Satellite observations show that lightning flashes in this region have higher radiances and have a larger spatial footprint than elsewhere in the tropics [Beirle et al., 2014]. Also, intracloud lightning flashes, which dissipate more energy, occur more frequently in this region [Cooray, 1997; Mackerras et al., 1998]. Lightning in GEOS-Chem is scaled by flash count and uses a single value for $\mathrm{LNO}_{x}$ produced per flash count in the tropics. Such parameterizations do not account for regional differences in flash radiance or length, or distinguish between intracloud and cloud-to-ground lightning and are thus likely affected by regional biases.

\subsection{Convection and Wet Deposition}

The effects of convective activity on $\mathrm{HNO}_{3}$ may play a role in the observed bias as Southeast Asia is a highly active convection region. Staudt et al. [2003] found that simulated $\mathrm{HNO}_{3}$ concentrations are sensitive to the convective mass flux due to both scavenging of $\mathrm{HNO}_{3}$ in updrafts and mixing of air in the boundary layer where it can be deposited. We explored the potential effect that convection has on modeled $\mathrm{HNO}_{3}$ by decreasing the convective mass flux by $25 \%$. Figure $5 f$ shows that this change in convective flux has little effect on the bias with respect to IASI tropospheric columns, increasing columns over the tropics by less than $15 \%$. We also tested the effect of wet deposition alone, by reducing the scavenging efficiency in GEOS-Chem. A $50 \%$ reduction in the scavenging efficiency leads to a $10 \%$ increase in tropospheric $\mathrm{HNO}_{3}$ columns. The reduction in solubility tested here is not physically likely, but these tests indicate that the convective scavenging scheme or errors in parameterized convection may play a role in the $\mathrm{HNO}_{3}$ bias, although the overall sensitivity of the bias to scavenging is small compared to changes in lightning $\mathrm{NO}_{x}$.

\section{Conclusions}

We analyzed IASI tropospheric $\mathrm{HNO}_{3}$ columns over the tropical ocean. IASI and GEOS-Chem tropospheric $\mathrm{HNO}_{3}$ columns are consistent within 10\% throughout most of the tropics. However, observations over Southeast Asia show column values twice as high as simulated values. This simulated $\mathrm{HNO}_{3}$ bias was supported by aircraft measurements (PEM-West B and PEM-Tropics A) and observations from the ACE-FTS and HIRDLS satellite instruments. Comparison of IASI and GEOS-Chem CO did not indicate a bias, implying large-scale transport errors are an unlikely explanation for the $\mathrm{HNO}_{3}$ bias.

Investigation into the source of the model bias indicates sensitivity to the lightning $\mathrm{NO}_{x}$ parameterization. We found that direct changes to the lightning $\mathrm{NO}_{x}$ source was unlikely to explain the bias as a large (factor of 3.5) increase was needed, which in turn led to a $25 \%$ bias in simulated ozone concentrations relative to ozonesonde observations. Studies examining the sensitivity of tropospheric $\mathrm{HNO}_{3}$ columns to the vertical distribution of lightning $\mathrm{NO}_{x}$ emissions indicated that increasing the $\mathrm{NO}_{x}$ injection height had little effect on the simulation bias, although it led to increased column abundances by $25 \%$ away from the region of emission. A simple parameterization accounting for nonlinearities in the conversion of $\mathrm{NO}_{x}$ to $\mathrm{HNO}_{3}$ in the beginning stage of the lightning $\mathrm{NO}_{x}$ plume and the related ozone production chemistry was implemented with moderate success. A prescribed subgrid ozone production efficiency of $15 \mathrm{~mol} / \mathrm{mol}$ in conjunction with an additional $0.5 \mathrm{Tg} \mathrm{N}$ added over Southeast Asia reduced the bias in that region from $92 \%$ to $6 \%$ with minimal impact on simulated ozone concentrations.

We also found some sensitivity of the model bias to convection processes, both in convective mass flux and the $\mathrm{HNO}_{3}$ wet deposition parameterization. Improved agreement between IASI and GEOS-Chem in convectively active regions was achieved by either reducing the convective mass flux or the efficiency of wet scavenging in convective although the overall effects were small. The most likely solution to the model bias will include changes to multiple processes, although changes to lightning $\mathrm{NO}_{x}$ may have a greater effect.

Future work should consider a more sophisticated lightning plume model in which the OPE depends on local dilution rates, perhaps similar to the parameterization for ship emissions [Vinken et al., 2011]. Additional processes not tested here, including errors in $\mathrm{HNO}_{3}$ production from $\mathrm{NO}_{2}, \mathrm{HNO}_{3}$ photolysis in clouds, PAN chemistry, or uptake of $\mathrm{HNO}_{3}$ by ice crystals [von Kuhlmann and Lawrence, 2006] may play a role. The recent development of a stratospheric $\mathrm{HNO}_{3}$ simulation for GEOS-Chem by Eastham et al. [2014] will aid future efforts to separate stratospheric and tropospheric components from the IASI total columns. 


\section{Acknowledgments}

IASI $\mathrm{HNO}_{3}$ data are available on request by contacting P.-F Coheur. IASI CO data were provided by LATMOS/CNRS and ULB and are available online at the Ether database at http://www.pole-ether.fr/. HIRDLS data products are available online at NASA's Goddard Earth Sciences Data and Information Services Center. ACE-FTS data are available on request by contacting the ACE Science Team at info@scisat.ca. Aircraft data from PEM West and PEMTropics campaigns are made available online at NASA's Global Tropospheric Experiment webpage at http://www-gte. larc.nasa.gov/gte_fld.htm. SHADOZ ozonesonde measurements are available online at http://croc.gsfc.nasa.gov/shadoz/. Information on accessing GEOS-Chem code can be found online at geos-chem. org. This work was supported by the Natural Sciences and Engineering Research Council of Canada. P.-F. Coheur and C. Wespes are, respectively, Senior Research Associate and Postdoctoral Researcher with F.R.S.-FNRS. The research in Belgium was also funded by the Belgian State Federal Office for Scientific, Technical and Cultural Affairs and the European Space Agency (ESA Prodex IASI.Flow), as well as by EUMETSAT (O3MSAF).

\section{References}

Barkley, M. P., et al. (2011), Can a "state of the art" chemistry transport model simulate Amazonian tropospheric chemistry?, J. Geophys. Res., 116, D16302, doi:10.1029/2011JD015893.

Beirle, S., W. Koshak, R. Blakeslee, and T. Wagner (2014), Global patterns of lightning properties derived by OTD and LIS, Nat. Hazards Earth Syst. Sci. Discuss., 2, 2765-2787, doi:10.5194/nhessd-2-2765-2014.

Bernath, P. F., et al. (2005), Atmospheric Chemistry Experiment (ACE): Mission overview, Geophys. Res. Lett., 32, L15S01, doi:10.1029/ 2005GL022386.

Bey, I., D. J. Jacob, R. M. Yantosca, J. A. Logan, B. Field, A. M. Fiore, Q. Li, H. Liu, L. J. Mickley, and M. Schultz (2001), Global modeling of tropospheric chemistry with assimilated meteorology: Model description and evaluation, J. Geophys. Res., 106, 23,073-23,096, doi:10.1029/2001JD000807.

Brunner, D., et al. (2005), An evaluation of the performance of chemistry transport models-Part 2: Detailed comparison with two selected campaigns, Atmos. Chem. Phys., 5, 107-129, doi:10.5194/acp-5-107-2005.

Clerbaux, C., et al. (2009), Monitoring of atmospheric composition using the thermal infrared IASI/MetOp sounder, Atmos. Chem. Phys., 9, 6041-6054.

Cooper, M., R. V. Martin, B. Sauvage, C. D. Boone, K. A. Walker, P. F. Bernath, C. A. McLinden, D. A. Degenstein, A. Volz-Thomas, and C. Wespes (2011), Evaluation of ACE-FTS and OSIRIS satellite retrievals of ozone and nitric acid in the tropical upper troposphere: Application to ozone production efficiency, J. Geophys. Res., 116, D12306, doi:10.1029/2010JD015056.

Cooray, V. (1997), Energy dissipation in lightning flashes, J. Geophys. Res., 102(D17), 21,401-21,410, doi:10.1029/96JD01917.

Eastham, S. D., D. K. Weisenstein, and S. R. H. Barrett (2014), Development and evaluation of the unified tropospheric-stratospheric chemistry extension (UCX) for the global chemistry-transport model GEOS-Chem, Atmos. Environ., 89, 52-63, doi:10.1016/j.atmosenv.2014.02.001.

Folkins, I., P. Bernath, C. Boone, L. J. Donner, A. Eldering, G. Lesins, R. V. Martin, B.-M. Sinnhuber, and K. Walker (2006), Testing convective parameterizations with tropical measurements of $\mathrm{HNO}_{3}, \mathrm{CO}, \mathrm{H}_{2} \mathrm{O}$, and $\mathrm{O}_{3}$ : Implications for the water vapor budget, J. Geophys. Res. 111, D23304, doi:10.1029/2006JD007325.

George, M., et al. (2009), Carbon monoxide distributions from the IASI/METOP mission: Evaluation with other space-borne remote sensors, Atmos. Chem. Phys., 9, 8317-8330, doi:10.5194/acp-9-8317-2009.

Gille, J. C., et al (1984), Accuracy and precision of the nitric acid concentration determined by the Limb Infrared Monitor of the Stratosphere experiment on the Nimbus 7, J. Geophys. Res., 89, 5179-5190, doi:10.1029/JD089iD04p05179.

Gilmore, C. K., S. R. H. Barrett, J. Koo, and Q. Wang (2013), Temporal and spatial variability in the aviation $\mathrm{NO}_{x}$-related $\mathrm{O}_{3}$ impact, Environ. Res. Lett., 8, 034,027, doi:10.1088/1748-9326/8/3/034027.

Giorgi, F., and W. L. Chameides (1986), Rainout lifetimes of highly soluble aerosols and gases as inferred from simulations with a generalcirculation model, J. Geophys. Res., 91, 14,367-14,376, doi:10.1029/JD091iD13p14367.

Guenther, A. B., X. Jiang, C. L. Heald, T. Sakulyanontvittaya, T. Duhl, L. K. Emmons, and X. Wang (2012), The Model of Emissions of Gases and Aerosols from Nature version 2.1 (MEGAN2.1): An extended and updated framework for modeling biogenic emissions, Geosci. Model Dev. Discuss., 5, 1503-1560, doi:10.5194/gmdd-5-1503-2012.

Hoell, J. M., D. D. Davis, S. C. Liu, R. E. Newell, H. Akimoto, R. J. McNeal, and R. J. Bendura (1997), The Pacific Exploratory Mission-West Phase B: February-March, 1994, J. Geophys. Res., 102(D23), 28,223-28,239, doi:10.1029/97JD02581.

Hoell, J. M., D. D. Davis, D. J. Jacob, M. O. Rodgers, R. E. Newell, H. E. Fuelberg, R. J. McNeal, J. L. Raper, and R. J. Bendura (1999), Pacific Exploratory Mission in the tropical Pacific: PEM-Tropics A, August-September 1996, J. Geophys. Res., 104(D5), 5567-5583, doi:10.1029/1998JD100074.

Huntrieser, $\mathrm{H}$., et al. (2002), Airborne measurements of $\mathrm{NO}_{x}$, tracer species, and small particles during the European Lightning Nitrogen Oxides Experiment, J. Geophys. Res., 107(D11), 4113, doi:10.1029/2000JD000209.

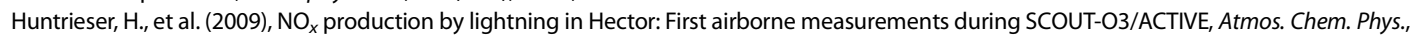
9, 8377-8412, doi:10.5194/acp-9-8377-2009.

Hurtmans, D., P.-F. Coheur, C. Wespes, L. Clarisse, O. Scharf, C. Clerbaux, J. Hadji-Lazaro, M. George, and S. Turquety (2012), FORLI radiative transfer and retrieval code for IASI, J. Quant. Spectros. Radiat. Transf., 113(11), 1391-1408.

Jaeglé, J., D. J. Jacob, Y. Wang, A. J. Weinheimer, B. A. Ridley, T. L. Campos, G. W. Sachse, and D. E. Hagen (1998), Sources and chemistry of NO in the upper troposphere over the United States, Geophys. Res. Lett., 25(10), 1705-1708, doi:10.1029/97GL03591.

Kasibhatla, P. S., H. Levey II, and W. J. Moxim (1993), Global $\mathrm{NO}_{x}, \mathrm{HNO}_{3}, \mathrm{PAN}$, and $\mathrm{NO}_{y}$ distributions from fossil fuel combustion emissions: A model study, J. Geophys. Res., 98(D4), 7165-7180, doi:10.1029/92JD02845.

Kinnison, D. E., et al. (2008), Global observations of $\mathrm{HNO}_{3}$ from the High Resolution Dynamics Limb Sounder (HIRDLS): First results, J. Geophys. Res., 113, D16S44, doi:10.1029/2007JD008814.

Kleinman, L. I., P. H. Daum, Y.-N. Lee, L. J. Nunnermacker, S. R. Springston, J. Weinstein-Lloyd, and J. Rudolph (2002), Ozone production efficiency in an urban area, J. Geophys. Res., 107(D23), 4733, doi:10.1029/2002JD002529.

Koshak, W. J., H. Peterson, A. Biazar, M. Khan, and L. Wang (2013), The NASA Lightning Nitrogen Oxides Model (LNOM): Application to air quality modeling, Atmos. Res., doi:10.1016/j.atmosres.2012.12.015.

Labrador, L. J., R. von Kuhlmann, and M. G. Lawrence (2005), The effects of lightning-produced $\mathrm{NO}_{x}$ and its vertical distribution on atmospheric chemistry: Sensitivity simulations with MATCH-MPIC, Atmos. Chem. Phys., 5, 1815-1834, doi:10.5194/acp-5-1815-2005.

Lin, X., M. Trainer, and S. C. Liu (1988), On the nonlinearity of the tropospheric ozone production (1988), J. Geophys. Res., 93(D12), 15,879-15,888, doi:10.1029/JD093iD12p15879.

Liu, H., D. J. Jacob, I. Bey, and R. M. Yantosca (2001), Constraints from ${ }^{210} \mathrm{~Pb}$ and ${ }^{7}$ Be on wet deposition and transport in a global three-dimensional chemical tracer model driven by assimilated meteorological fields, J. Geophys. Res., 101(D11), 12,109-12,128, doi:10.1029/2000JD900839.

Liu, S. C., M. Trainer, F. C. Fehsenfeld, D. D. Parrish, E. J. Williams, D. W. Fahey, G. Huebler, and P. C. Murphy (1987), Ozone production in the rural troposphere and the implications for regional and global ozone distributions, J. Geophys. Res., 92, 4191-4207, doi:10.1029/JD092iD04p04191.

Mackerras, D., M. Darveniza, R. E. Orville, E. R. Williams, and S. J. Goodman (1998), Global lightning: Total, cloud and ground flash estimates, J. Geophys. Res., 103(D16), 19,791-19,809, doi:10.1029/98JD01461.

Mao, J., et al. (2010), Chemistry of hydrogen oxide radicals $\left(\mathrm{HO}_{x}\right)$ in the Arctic troposphere in spring, Atmos. Chem. Phys., 10(13), 5823-5838, doi:10.5194/acp-10-5823-2010.

Mari, C., D. J. Jacob, and P. Bechtold (2000), Transport and scavenging of soluble gases in a deep convective cloud, J. Geophys. Res., 105(D17), 22,255-22,267, doi:10.1029/2000JD900211.

Martin, R. V., et al. (2002), Interpretation of TOMS observations of tropical tropospheric ozone with a global model and in situ observations, J. Geophys. Res., 107(D18), 4351, doi:10.1029/2001JD001480.

Martin, R. V., B. Sauvage, I. Folkins, C. E. Sioris, C. Boone, P. Bernath, and J. R. Ziemke (2007), Space-based constraints on the production of nitric oxide by lightning, J. Geophys. Res., 112, D09309, doi:10.1029/2006JD007831. 
McLinden, C. A., S. C. Olsen, B. Hannegan, O. Wild, M. J. Prather, and J. Sundet (2000), Stratospheric ozone in 3-D models: A simple chemistry and the cross-tropopause flux, J. Geophys. Res., 105(D11), 14,653-14,665, doi:10.1029/2000JD900124.

Meijer, E. W., P. F. J. van Velthoven, W. M. F. Wauben, J. P. Beck, and G. J. M. Velders (1997), The effects of the conversion of nitrogen oxides in aircraft exhaust plumes in global models, Geophys. Res. Lett., 24(23), 3013-3016, doi:10.1029/97GL53156.

Miyazaki, K., H. J. Eskes, K. Sudo, and C. Zhang (2014), Global lightning $\mathrm{NO}_{x}$ production estimated by an assimilation of multiple satellite data sets, Atmos. Chem. Phys., 14, 3277-3305, doi:10.5194/acp-14-3277-2014.

Moorthi, S., and M. J. Suarez (1992), Relaxed Arakawa-Schubert, a parameterization of moist convection for general circulation models, Mon. Weather Rev., 120, 978-1002.

Murray, L. T., D. J. Jacob, J. A. Logan, R. C. Hudman, and W. J. Koshak (2012), Optimized regional and interannual variability of lightning in a global chemical transport model constrained by LIS/OTD satellite data, J. Geophys. Res., 117, D20307, doi:10.1029/2012JD017934.

Murray, L. T., J. A. Logan, and D. J. Jacob (2013), Interannual variability in tropical tropospheric ozone and OH: The role of lightning, J. Geophys. Res. Atmos., 118, 11,468-11,480, doi:10.1002/jgrd.50857.

Olivier, J. G. (2001), Global Emissions Sources and Sinks, The Climate System, A.A. Balkema Publishers/Sweets \& Zeitlinger Publishers, Lisse, Netherlands.

Ott, L. E., K. E. Pickering, G. L. Stenchikov, D. J. Allen, A. J. DeCaria, B. Ridley, R.-F. Lin, S. Lang, and W.-K. Tao (2010), Production of lightning $\mathrm{NO}_{x}$ and its vertical distribution calculated from three-dimensional cloud-scale chemical transport model simulations, J. Geophys. Res., 115, D04301, doi:10.1029/2009JD011880

Pickering, K. E., A. M. Thompson, R. R. Dickerson, W. T. Luke, D. P. McNamara, J. P. Greenberg, and P. R. Zimmerman (1990), Model calculations of tropospheric ozone production potential following observed convective events, J. Geophys. Res., 95(D9), 14,049-14,062, doi:10.1029/JD095iD09p14049.

Rodgers, C. D., and B. J. Conner (2003), Intercomparison of remote sounding instruments, J. Geophys. Res., 108(D3), 4116, doi:10.1029/2002JD002299.

Santee, M. L., G. L. Manney, N. J. Livesey, and W. G. Read (2004), Three-dimensional structure and evolution of stratospheric $\mathrm{HNO}_{3}$ based on UARS Microwave Limb Sounder measurements, J. Geophys. Res., 109, D15306, doi:10.1029/2004JD004578.

Sauvage, B., R. V. Martin, A. van Donkelaar, and J. R. Ziemke (2007), Quantification of the factors controlling tropical tropospheric ozone and the South Atlantic maximum, J. Geophys. Res., 112, D11309, doi:10.1029/2006JD008008.

Schumann, U., and H. Huntrieser (2007), The global lightning-induced nitrogen oxides source, Atmos. Chem. Phys., 7, 3823-3907, doi:10.5194/acp-7-3823-2007.

Sillman, S., J. A. Logan, and S. C. Wofsy (1990), A regional scale model for ozone in the United States with subgrid representation of urban and power plant plumes, J. Geophys. Res., 95(D5), 5731-5748, doi:10.1029/JD095iD05p05731.

Singh, H. B., et al. (2007), Reactive nitrogen distribution and partitioning in the North American troposphere and lowermost stratosphere, J. Geophys. Res., 112, D12S04, doi:10.1029/2006JD007664.

Staudt, A. C., D. J. Jacob, F. Ravetta, J. A. Logan, D. Bachiochi, T. N. Krishnamurti, S. Sandholm, B. Ridley, H. B. Singh, and B. Talbot (2003), Sources and chemistry of nitrogen oxides over the tropical Pacific, J. Geophys. Res., 108(D2), 8239, doi:10.1029/2002JD002139.

Stevenson, D. S., et al. (2013), Tropospheric ozone changes, radiative forcing and attribution to emissions in the Atmospheric Chemistry and Climate Model Intercomparison Project (ACCMIP), Atmos. Chem. Phys., 13, 3063-3085, doi:10.5194/acp-13-3063-2013.

Thompson, A. M., et al. (2003a), Southern Hemisphere Additional Ozonesondes (SHADOZ) 1998-2000 tropical ozone climatology: 1. Comparison with Total Ozone Mapping Spectrometer (TOMS) and ground-based measurements, J. Geophys. Res., 108(D2), 8238, doi:10.1029/2001JD000967.

Thompson, A. M., et al. (2003b), Southern Hemisphere Additional Ozonesondes (SHADOZ) 1998-2000 tropical ozone climatology: 2. Tropospheric variability and the zonal wave-one, J. Geophys. Res., 108(D2), 8241, doi:10.1029/2002JD002241.

Tost, H., P. J. Joeckel, and J. Lelieveld (2007), Lightning and convection parameterisations-Uncertainties in global modelling, Atmos. Chem. Phys., $7(17), 4553-4568$

Tsidu, G. M., et al. (2005), $\mathrm{NO}_{y}$ from Michelson Interferometer for passive atmospheric sounding on environmental satellite during the Southern Hemisphere polar vortex split in September/October 2002, J. Geophys. Res., 110, D11301, doi:10.1029/2004JD005322.

van der Werf, G. R., J. T. Randerson, L. Giglio, G. J. Collatz, M. Mu, P. S. Kasibhatla, D. C. Morton, R. S. DeFries, Y. Jin, and T. T. van Leeuwen (2010), Global fire emissions and the contribution of deforestation, savanna, forest, agricultural, and peat fires (1997-2009), Atmos. Chem. Phys., 10, 11,707-11,735, doi:10.5194/acp-10-11707-2010.

Vinken, G. C., K. F. Boersma, D. J. Jacob, and E. W. Meijer (2011), Accounting for non-linear chemistry of ship plumes in the GEOS-Chem global chemistry transport model, Atmos. Chem. Phys., 11, 11,707-11,722, doi:10.5194/acp-11-11707-2011.

Von Kuhlmann, R., and M. G. Lawrence (2006), The impact of ice uptake of nitric acid on atmospheric chemistry, Atmos. Chem. Phys., 6, 225-235.

Wang, Q., D. J. Jacob, J. R. Spackman, A. E. Perring, J. P. Schwarz, N. Moteki, E. A. Marais, C. Ge, J. Wang, and S. R. H. Barrett (2013), Global budget and radiative forcing of black carbon aerosol: Constraints from pole-to-pole (HIPPO) observations across the Pacific, J. Geophys. Res. Atmos., 119, 195-206, doi:10.1002/2013JD020824.

Wespes, C., D. Hurtmans, C. Clerbaux, M. L. Santee, R. V. Martin, and P. F. Coheur (2009), Global distributions of nitric acid from IASI/MetOP measurements, Atmos. Chem. Phys., 9, 7949-7962.

Wolff, M. A., et al. (2008), Validation of $\mathrm{HNO}_{3}, \mathrm{ClONO}_{2}$, and $\mathrm{N}_{2} \mathrm{O}_{5}$ from the Atmospheric Chemistry Experiment Fourier Transform Spectrometer (ACE-FTS), Atmos. Chem. Phys., 8, 3529-3562, doi:10.5194/acp-8-3529-2008.

Zhang, L., D. J. Jacob, X. Liu, J. A. Logan, K. Chance, A. Eldering, and B. R. Bojkov (2010), Intercomparison methods for satellite measurements of atmospheric composition: Application to tropospheric ozone from TES and OMI, Atmos. Chem. Phys., 10, 4725-4739, doi:10.5194/ acp-10-4725-2010. 